\title{
Relationship between environmental conditions and recovery of the coral reefs in the Andaman coast of Thailand
}

\author{
Nissara Thawonsode ${ }^{\mathrm{a}}$, Shettapong Meksumpun ${ }^{\mathrm{a}, \mathrm{b}, *}$, Pattira Kasamesiri $^{\mathrm{c}}$ \\ a Department of Marine Science, Faculty of Fisheries, Kasetsart University, Chatuchak, \\ Bangkok 10900 Thailand \\ b Centre of Advanced Studies in Tropical Natural Resources, KU Institute for Advanced Studies, \\ Kasetsart University, Bangkok 10900 Thailand \\ c Department of Agriculture, Faculty of Technology, Mahasarakham University, \\ Mahasarakham 44000 Thailand
}

${ }^{*}$ Corresponding author, e-mail: ffisspm@ku.ac.th

Received 13 Oct 2014

Accepted 22 Jul 2015

\begin{abstract}
The coral reef ecosystem in the Andaman sea was studied by monitoring aquatic environmental conditions and reef condition from years 2005-2009. Following the Asian tsunami in December 2004, the ammonium-nitrogen concentration in the surface water in Ranong province ranged from 8.45-14.08 $\mu \mathrm{M}$, while in Phang Nga area, it was between 9.99 and $25.11 \mu \mathrm{M}$. Mean sea surface temperatures in Ranong and Phang Nga were $30.6 \pm 0.4^{\circ} \mathrm{C}$ during the dry season. The growth rate of Acropora spp. in Chong Khat bay, Surin Marine National Park, was $1.0 \mathrm{~cm} / \mathrm{month}$ during the first 5 months after the tsunami. After this five-month period, corals, especially Acropora spp., showed signs of recovery but then faced extensive bleaching in May 2005. Three years after the tsunami, the coral reefs in deep water areas could grow and recover rapidly although they faced serious bleaching while coral reefs in the shallower waters were in a poor condition after serious bleaching in May 2005. This phenomenon revealed that the mass mortality of corals in shallow waters was enhanced by high seawater temperature and high turbidity due to phytoplankton blooms. Overall results indicate that the relationships between environmental conditions and coral reef status in the Andaman sea is an issue of great concern and coastal corals may gradually degrade in the near future unless action is taken to alleviate coastal environmental problems.
\end{abstract}

KEYWORDS: coral bleaching, red tide, tsunami

\section{INTRODUCTION}

Many coral reefs, especially those along the Andaman shoreline and in adjacent narrow channels of Thai water, were severely damaged by the gigantic tsunami caused by the $9.3 \mathrm{Mw}$ SumatraAndaman earthquake ${ }^{1}$ which occurred on 26 December 2004. To evaluate the impacts of the tsunami, an emergency research team led by the Department of Marine and Coastal Resources (DMCR) of the Ministry of Natural Resources and Environment (MONRE), including nine educational institutions (Burapha University, Chulalongkorn University, Kasetsart University, Mahidol University, Prince of Songkhla University, Rajamangala Institute of Technology, Ramkamhaeng University, and Walailak University) was formed. The assessment of the destructive impact of the tsunami on the coral reefs began within a couple of days after it occurred. The results from that study showed that the destructive impact of the tsunami on coral reefs depended on the geographic location of shorelines, islands, and reefs. Most of the coral reefs in Ranong and Phang Nga were not damaged (less than $30 \%$ of corals were affected). The more severely damaged coral reefs (more than 50\% affected) were found in Chong Khat bay (Surin Marine National Park, Phang Nga), Lan, Kam Yai, and Khang Khao islands, Ranong (unpublished English-language data). Half of the coral reef in the north-eastern part of Jolly Buoy island, Andaman and Nicobar islands died due to the tsunami ${ }^{2}$. A few months after the tsunami, Ranong and Phang Nga reefs faced serious problems of coral bleaching and phytoplankton blooms, particular during our coastal surveys in May 2005.

Coral bleaching is not a new phenomenon in coastal areas with high incidences reported in several regions over the last two decades ${ }^{3-9}$. Coral 
bleaching in the Andaman sea has also been reported $^{10-12}$. Extensive coral mortality by coral bleaching in the Andaman sea was observed in 1991 and 1995 . Pongsuwan ${ }^{11}$ reported that $80 \%$ mortality of Acropora spp. occurred at Surin and Similan islands in 1995. Previous studies have suggested that coral bleaching were caused by high temperature or irradiance ${ }^{13-18}$. Fitt ${ }^{19}$ suggested that it is caused by thermal tolerance limits and thermal thresholds in several tropical corals. However, quantitative and qualitative analysis of these factors, including anomaly excursion, length and exposure timing, has not been done ${ }^{18}$. Coral bleaching in the Andaman sea seemed to be an annual event ${ }^{20}$.

In addition, coral reef along the Andaman coast line faced the problem of an increase in turbidity. In fact, the Andaman sea has faced problems of nutrient loading, red tide, and macroalgal blooms several times after the tsunami in 2004. Since phytoplankton bloom increases water turbidity and decreases the amount of light available to zooxanthellae in coral polyp, increases phytoplankton levels could have both direct and indirect effects on the growth rate of corals. Thus to understand the changes in the status of coral reefs exposed stressful environmental conditions, the physicochemical characteristics of sea water, degree of coral bleaching, and the growth of corals were examined from 2005-2009. The goal of this study is to clarify the relationships between the environmental conditions and coral reef status in the study area. The output from this study should contribute to coral reef management of the coastal areas.

\section{MATERIALS AND METHODS}

\section{Sampling and site}

This study focused on three topic areas. Firstly, seawater characteristic analysis was conducted in March 2005 (Ranong province) and in March 2006 (Phang Nga province). Secondly, the incidences of red tide were monitored in March 2005, 2006, and October 2009. Finally, the coral bleaching incident (in May 2005), growth, and recovery of coral (in May 2005, February 2007 and October 2009) were examined. One hundred and thirty two sampling stations covered all study areas (near shore and off shore) were designed as shown in Figs. 1 and 2 .

Ranong and Phang Nga are located at the first and second southern provinces, respectively, on the Andaman coast of Thailand. The coast along these provinces is submerged with a narrow continental shelf. More than 160 islands belongs to Ranong

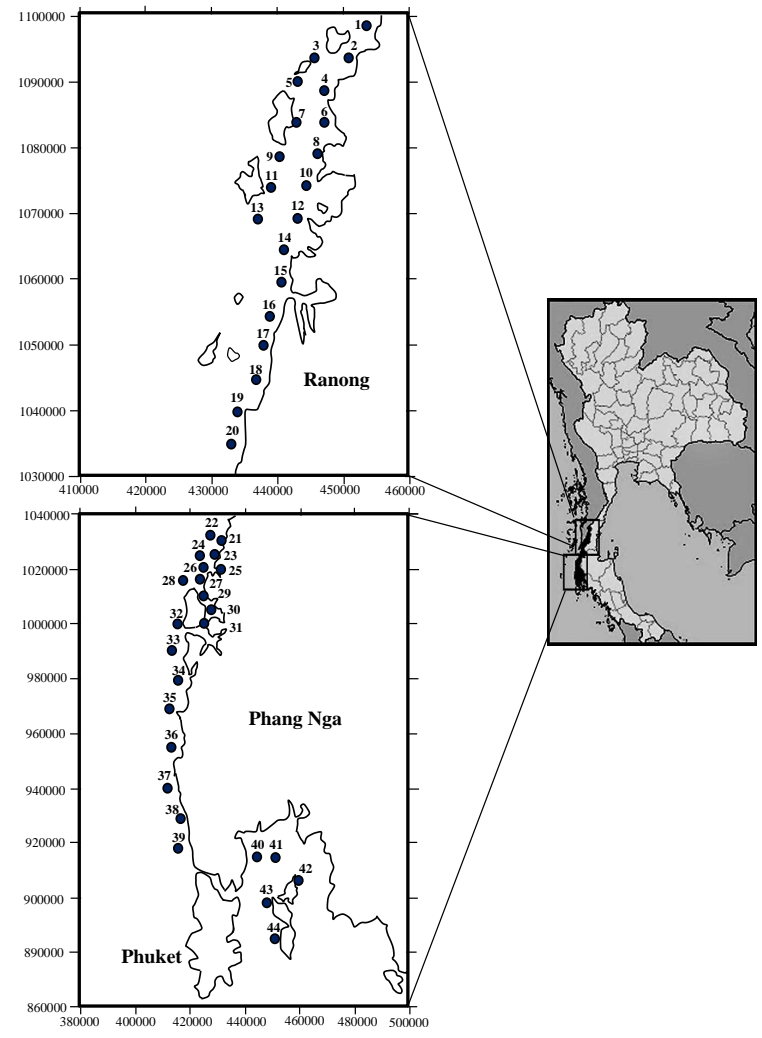

Fig. 1 Sampling locations (44 stations) for seawater characteristics in Ranong (March 2005) and Phang Nga provinces (March 2006).

and Phang Nga provinces. Phayam island is a large island with an area of approximately 35 square kilometres. We can find coral reef at both East and West coast of the island. The most beautiful and famous diving site of the near-shore area is Khang Khao island. Most of the coral reefs of near shore islands in study area are shallow fringing reefs. In our study area, rainy season span about 8 months (MayDecember) each year. High volume of water from rain compensates for the evaporation and results in an average salinity of less than $34 \mathrm{psu}^{21}$. Suspended solids usually affect the water transparency especially along the coastal areas during rainy season. The appropriate time for scuba diving is only four months during the dry season.

The Andaman sea is generally clean and clear during the dry season. Surin Marine National Park has an aquatic area of 102 square kilometres with about $60 \mathrm{~km}$ far away from the main land (Phang Nga province). The most dominant genus of coral in this area is Porites followed by Acropora ${ }^{22}$. 


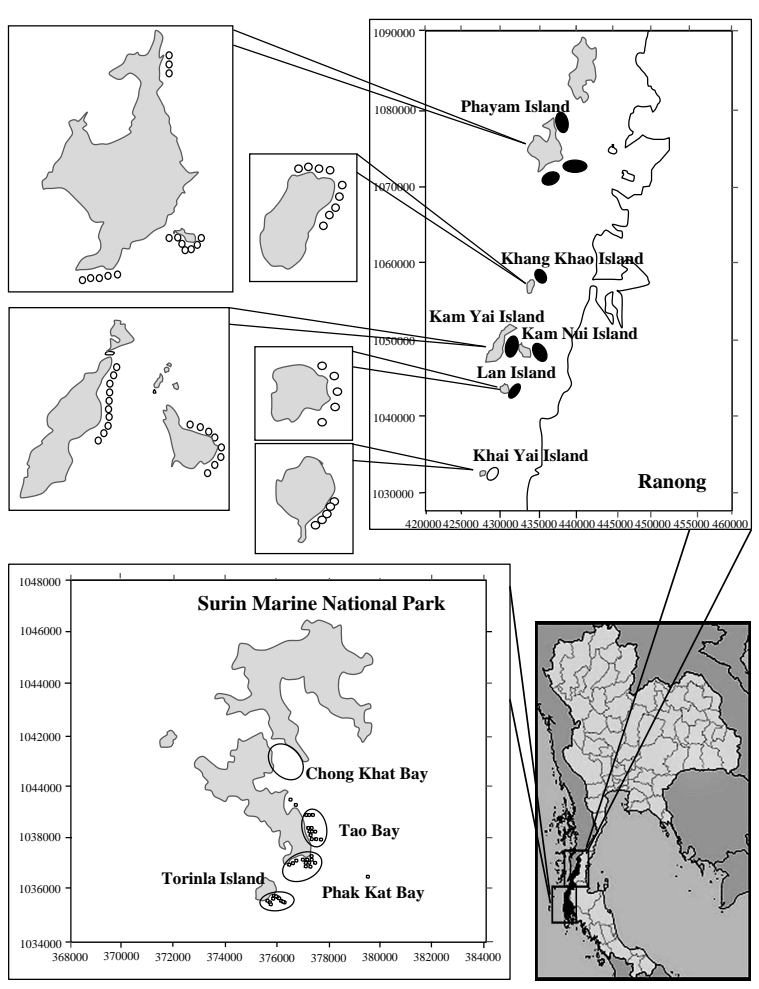

Fig. 2 Map of sampling area around Ranong (52 sampling stations (15 stations at Phayam island; 18 stations at Kam Yai and Kam Nui islands; 9 stations at Khang Khao island; 5 stations at Lan island; 5 stations at Khai Yai island (closed circle)) for coral bleaching survey and 8 sites (dash ellipse) for coral growth measurement) and Surin Marine National Park (36 stations (open circle) for coral bleaching survey and 4 sites (dash ellipse) for coral growth measurement).

\section{Environmental factors and red tide incidence}

At least two water samples were obtained from each sampling station along the Andaman sea coasts in Ranong and Phang Nga provinces, Thailand. A total of 44 stations in Thai waters were sampled (Fig. 1). Water samples were collected at a depth of $30 \mathrm{~cm}$ with a Van-Dorn bottle sampler. Water temperature and salinity were also measured using a multiparameter water quality monitor (YSI 6600). To avoid the impact of different stages of the tidal cycle on seawater characteristics, water sampling was conducted on a speed boat to complete the sample collections within three days, during flood tide only. The incidence of red tide was also recorded during the field survey.

\section{Chemical analysis}

For nutrient analysis, 20-ml aliquots of water samples were filtered through Whatman GF/F filter paper. All nutrient samples were kept frozen at $-40^{\circ} \mathrm{C}$. Concentrations of ammonium-nitrogen, silicatesilicon and orthophosphate-phosphorus were then analysed by a nutrient auto-analyser (Skalar San Plus) within one week after sampling.

For chlorophyll a analysis, approximately $100 \mathrm{ml}$ of each water sample was filtered through Whatman GF/F filter paper and chlorophyll $a$ was extracted from the filters with $90 \%$ acetone solution. Chlorophyll a concentration was then determined by spectrophotometric method ${ }^{23}$.

\section{Measurement of coral bleaching}

Measurement of coral bleaching was conducted along the coastlines of Ranong and Phang Nga in May 2005 (Fig. 2). The surveys were performed using line transects of $20-60 \mathrm{~m}$ in length at Ranong province with a total of 52 sampling stations (15 stations at Phayam island, 18 stations at Kam Yai and Kam Nui islands, 9 stations at Khang Khao island, 5 stations at Lan island, and 5 stations at Khai Yai island). The length of line transects depended on the length of the reef flat and reef slope. The measurement of bleaching started from reef flat and ended at the end of reef slope. Since the coral reef of Surin and Torinla islands (Surin Marine National Park) at some stations have a long reef flat and very deep reef slope, the transect lines were set up at three depths (about 15, 20, and $25 \mathrm{~m}$ ) parallel to the shoreline. The measurement of bleaching was conducted at 36 sampling stations in Surin Marine National Park. The percentage of coral bleaching was calculated by measuring the proportion of living coral and bleached coral, along the transect lines.

\section{Measurement of coral growth}

Measurement of the growth of corals was conducted in various sites along the Andaman coast in May 2005, February 2007, and October 2009 (Fig. 2). Long term measurement of coral growth in the entire study area was very difficult to conduct using a permanent grid due to a high current speed and turbidity except at Surin Marine National Park. Hence 58 samples of Acropora spp. in Surin Marine National Park and 10 samples at near shore islands were selected randomly to measure the length of its primary branch (Fig. 3). In this current study, the growth rate of Acropora spp. in which the length of the branch of coral which had been overturned 


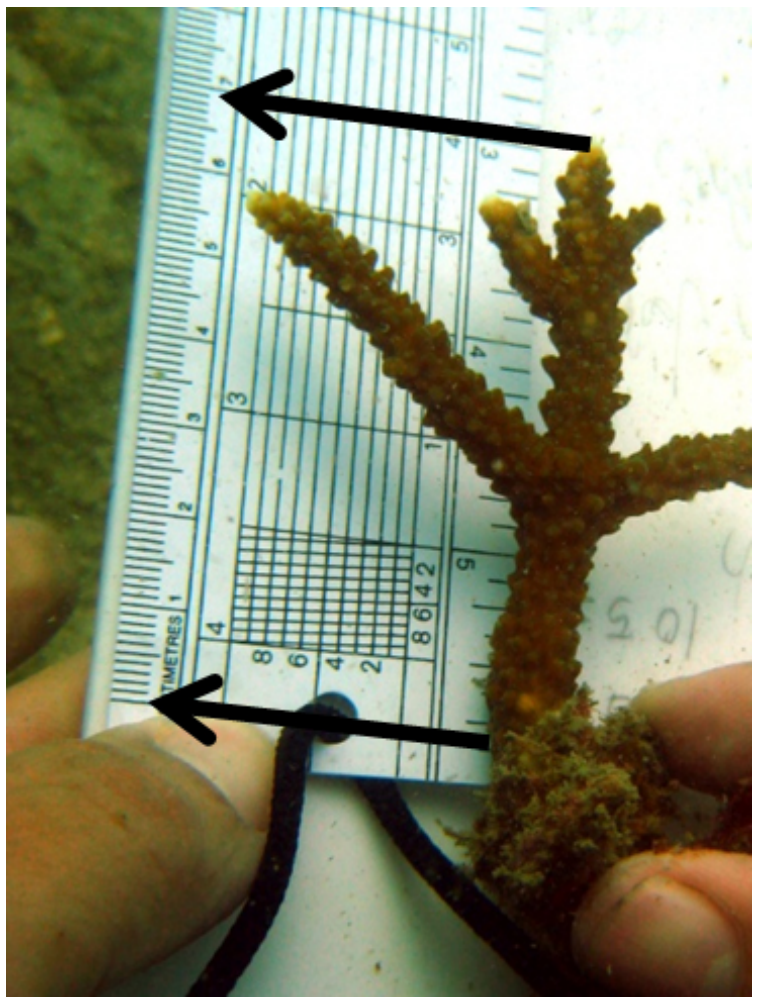

Fig. 3 Measurement of the length of Acropora's primary branch.

by the 2004 tsunami was monitored. Some parts of corals were brought back to the laboratory for species identification. Classification systems for corals was done according to Veron ${ }^{24}$.

\section{Data analysis}

Data from all measurements were compared using one-way ANOVA and $t$-tests after checking for normality and homoscedasticity. Coefficients of determinations were calculated where appropriate.

\section{RESULTS}

\section{Seawater characteristic}

Surface (depth of $30 \mathrm{~cm}$ ) water temperatures in Ranong ranged from $30.05-31.90^{\circ} \mathrm{C}$ while in Phang Nga, they ranged from $30.01-31.25^{\circ} \mathrm{C}$. The highest sea surface temperatures were found in the western part of Khao Bang Chang (station 6) and Khao Phing Kan (station 40) (Tables 1 and 2). The sea surface temperatures in 37 of the 44 sampling stations were higher than $30^{\circ} \mathrm{C}$. The mean sea surface temperature in Ranong and Phang Nga was $30.6 \pm 0.4^{\circ} \mathrm{C}$. Fig. 4 shows the vertical profile of the water temperatures at stations 6 (water depth
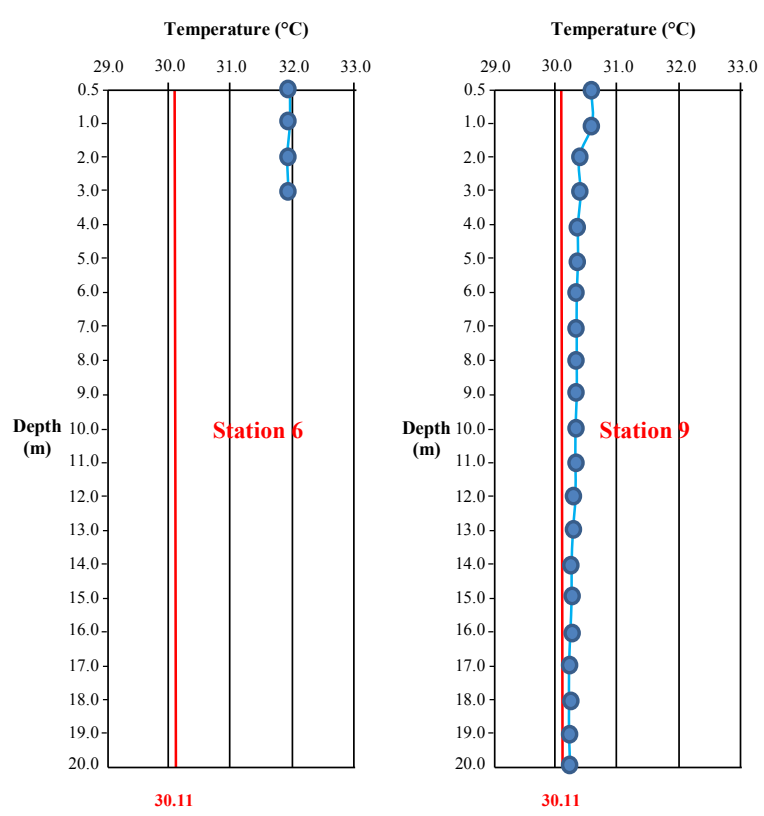

Fig. 4 Vertical profiles of temperature at stations 6 (left) and 9 (right).

$2.5 \mathrm{~m}$ ) and 9 (water depth $20 \mathrm{~m}$ ). These profiles indicate vertical mixing of water occurring around the study area.

Surface salinity in Ranong and Phang Nga ranged from $32.98-34.80$ and $32.90-33.41$ psu, respectively, (Tables 1 and 2). During the dry season, all sampling stations had a surface salinity higher than 32 psu. The lowest salinity in Ranong and Phang Nga was found at the Ranong river mouth (station 1) and Khao Phing Kan (station 40), respectively. In the case of silicate-silicon concentration, results showed that the highest concentration in surface waters was found at the mouth of Ranong river (Table 1). In Phang Nga, the concentration of silicate-silicon varied from 3.77-25.23 $\mu \mathrm{M}$ (Table 2). The highest concentration was found at Khao Phing Kan (station 40) where the lowest salinity was also found.

Ammonium-nitrogen concentration in surface water in Ranong ranged between 8.45 and $14.08 \mu \mathrm{M}$, while in Phang Nga, it ranged from 9.99-25.11 $\mu \mathrm{M}$ (Tables 1 and 2). The highest concentration in Phang Nga was found at Ban Thai Mueang (station 38), an area which suffered severe damage from the 2004 tsunami. Orthophosphatephosphorus concentrations of surface water in Ranong ranged between 0.34 and $0.77 \mu \mathrm{M}$, while in Phang Nga the values ranged from $0.13-0.49 \mu \mathrm{M}$. The highest concentration was found at the mouth 
Table 1 Seawater characteristics of surface water in Ranong water (March 2005), the Andaman sea, Thailand.

\begin{tabular}{|c|c|c|c|c|c|c|c|c|}
\hline \multirow[t]{2}{*}{ Station } & \multicolumn{2}{|c|}{ UTM zone 47} & \multirow{2}{*}{$\begin{array}{l}\text { Temp } \\
\left({ }^{\circ} \mathrm{C}\right)\end{array}$} & \multirow{2}{*}{$\begin{array}{l}\text { Salinity } \\
\text { (psu) }\end{array}$} & \multirow{2}{*}{$\begin{array}{c}\mathrm{NH}_{4}^{+}-\mathrm{N} \\
(\mu \mathrm{M})\end{array}$} & \multirow{2}{*}{$\begin{array}{l}\mathrm{Si}(\mathrm{OH})_{4}-\mathrm{Si} \\
\quad(\mu \mathrm{M})\end{array}$} & \multirow{2}{*}{$\begin{array}{c}\mathrm{PO}_{4}^{3-}-\mathrm{P} \\
(\mu \mathrm{M})\end{array}$} & \multirow{2}{*}{$\begin{array}{l}\text { Chl } a \\
(\mu g / 1)\end{array}$} \\
\hline & $\mathrm{E}$ & $\mathrm{N}$ & & & & & & \\
\hline 1 & 453571 & 1100210 & 30.05 & 32.98 & 11.40 & 10.54 & 0.77 & 3.17 \\
\hline 2 & 450648 & 1095140 & 30.15 & 33.48 & 11.26 & 8.43 & 0.60 & 4.67 \\
\hline 3 & 445484 & 1095140 & 30.24 & 33.67 & 10.56 & 6.32 & 0.44 & 2.00 \\
\hline 4 & 446945 & 1090120 & 31.06 & 33.76 & 11.61 & 6.32 & 0.47 & 2.10 \\
\hline 5 & 442951 & 1091290 & 30.36 & 33.89 & 9.85 & 6.32 & 0.34 & 2.50 \\
\hline 6 & 447092 & 1085110 & 31.90 & 34.54 & 11.96 & 6.32 & 0.43 & 3.00 \\
\hline 7 & 442707 & 1085060 & 31.02 & 34.32 & 11.61 & 6.32 & 0.43 & 2.84 \\
\hline 8 & 445874 & 1080230 & 30.68 & 34.80 & 10.56 & 6.32 & 0.43 & 2.94 \\
\hline 9 & 440174 & 1079800 & 30.40 & 34.14 & 11.26 & 5.27 & 0.43 & 1.84 \\
\hline 10 & 444412 & 1075170 & 30.42 & 34.37 & 11.26 & 6.32 & 0.34 & 2.00 \\
\hline 11 & 438859 & 1074880 & 30.33 & 34.29 & 11.61 & 5.27 & 0.34 & 2.17 \\
\hline 12 & 442999 & 1070050 & 30.08 & 34.14 & 9.85 & 5.27 & 0.34 & 1.93 \\
\hline 13 & 436861 & 1070150 & 30.06 & 34.36 & 10.56 & 4.22 & 0.34 & 3.00 \\
\hline 14 & 440856 & 1065280 & 30.25 & 34.14 & 9.15 & 6.32 & 0.34 & 1.72 \\
\hline 15 & 440612 & 1059970 & 30.05 & 34.33 & 8.45 & 6.32 & 0.34 & 1.34 \\
\hline 16 & 438615 & 1054800 & 30.49 & 34.29 & 11.26 & 6.32 & 0.34 & 2.29 \\
\hline 17 & 437689 & 1050080 & 30.83 & 34.40 & 11.26 & 6.32 & 0.38 & 2.29 \\
\hline 18 & 436764 & 1044910 & 30.69 & 34.34 & 14.08 & 6.32 & 0.36 & 2.00 \\
\hline 19 & 433743 & 1039990 & 30.64 & 34.04 & 10.91 & 6.32 & 0.43 & 2.00 \\
\hline 20 & 432818 & 1034980 & 30.60 & 33.98 & 9.71 & 6.32 & 0.34 & 1.50 \\
\hline
\end{tabular}

Table 2 Seawater characteristics of surface water in Phang Nga water (March 2006), the Andaman sea, Thailand.

\begin{tabular}{|c|c|c|c|c|c|c|c|c|}
\hline \multirow[t]{2}{*}{ Station } & \multicolumn{2}{|c|}{ UTM zone 47} & \multirow{2}{*}{$\begin{array}{l}\text { Temp } \\
\left({ }^{\circ} \mathrm{C}\right)\end{array}$} & \multirow{2}{*}{$\begin{array}{c}\text { Salinity } \\
\text { (psu) }\end{array}$} & \multirow{2}{*}{$\begin{array}{c}\mathrm{NH}_{4}^{+}-\mathrm{N} \\
(\mu \mathrm{M})\end{array}$} & \multirow{2}{*}{$\begin{array}{l}\mathrm{Si}(\mathrm{OH})_{4}-\mathrm{Si} \\
\quad(\mu \mathrm{M})\end{array}$} & \multirow{2}{*}{$\begin{array}{c}\mathrm{PO}_{4}^{3-}-\mathrm{P} \\
(\mu \mathrm{M})\end{array}$} & \multirow{2}{*}{$\begin{array}{l}\text { Chl } a \\
(\mu g / 1)\end{array}$} \\
\hline & $\mathrm{E}$ & $\mathrm{N}$ & & & & & & \\
\hline 21 & 431356 & 1030110 & 30.76 & 33.91 & 10.56 & 6.32 & 0.30 & 2.17 \\
\hline 22 & 427540 & 1031926 & 30.47 & 33.85 & 11.26 & 6.32 & 0.38 & 0.83 \\
\hline 23 & 429115 & 1025180 & 30.14 & 33.82 & 9.99 & 6.32 & 0.26 & 1.17 \\
\hline 24 & 423694 & 1024281 & 30.51 & 33.31 & 19.56 & 5.66 & 0.49 & 1.34 \\
\hline 25 & 431521 & 1019691 & 30.63 & 34.41 & 16.19 & 7.38 & 0.47 & 6.45 \\
\hline 26 & 425267 & 1019920 & 30.60 & 33.86 & 10.56 & 6.32 & 0.26 & 1.63 \\
\hline 27 & 423853 & 1016095 & 30.10 & 33.95 & 11.26 & 5.27 & 0.26 & 1.34 \\
\hline 28 & 418074 & 1014906 & 30.46 & 33.47 & 18.37 & 6.76 & 0.41 & 0.95 \\
\hline 29 & 425121 & 1010230 & 30.66 & 34.24 & 10.91 & 6.32 & 0.34 & 2.00 \\
\hline 30 & 428287 & 1004920 & 30.18 & 34.32 & 11.96 & 6.32 & 0.34 & 2.00 \\
\hline 31 & 425364 & 1000050 & 30.38 & 34.13 & 10.56 & 6.32 & 0.26 & 1.17 \\
\hline 32 & 415679 & 999668 & 30.59 & 33.53 & 20.81 & 13.00 & 0.37 & 1.67 \\
\hline 33 & 413681 & 989878 & 30.01 & 33.52 & 18.17 & 4.81 & 0.32 & 0.67 \\
\hline 34 & 415960 & 978904 & 30.82 & 33.48 & 16.65 & 4.68 & 0.23 & 0.67 \\
\hline 35 & 412908 & 968564 & 30.84 & 33.56 & 16.39 & 5.40 & 0.13 & 0.57 \\
\hline 36 & 413486 & 954635 & 30.73 & 33.41 & 17.84 & 5.85 & 0.27 & 0.50 \\
\hline 37 & 411733 & 939455 & 30.62 & 33.48 & 14.54 & 5.72 & 0.45 & 1.11 \\
\hline 38 & 416527 & 928633 & 30.67 & 33.49 & 25.11 & 3.77 & 0.23 & 1.07 \\
\hline 39 & 416126 & 917281 & 30.54 & 33.46 & 14.21 & 5.85 & 0.33 & 0.57 \\
\hline 40 & 444675 & 914388 & 31.25 & 32.90 & 15.73 & 25.23 & 0.39 & 5.34 \\
\hline 41 & 451532 & 914518 & 31.12 & 33.20 & 16.52 & 19.38 & 0.26 & 4.01 \\
\hline 42 & 459710 & 905397 & 30.80 & 33.25 & 17.77 & 9.10 & 0.34 & 3.13 \\
\hline 43 & 448451 & 897409 & 30.85 & 33.12 & 17.84 & 10.99 & 0.36 & 4.01 \\
\hline 44 & 450947 & 884464 & 30.39 & 33.16 & 21.67 & 7.28 & 0.37 & 2.67 \\
\hline
\end{tabular}



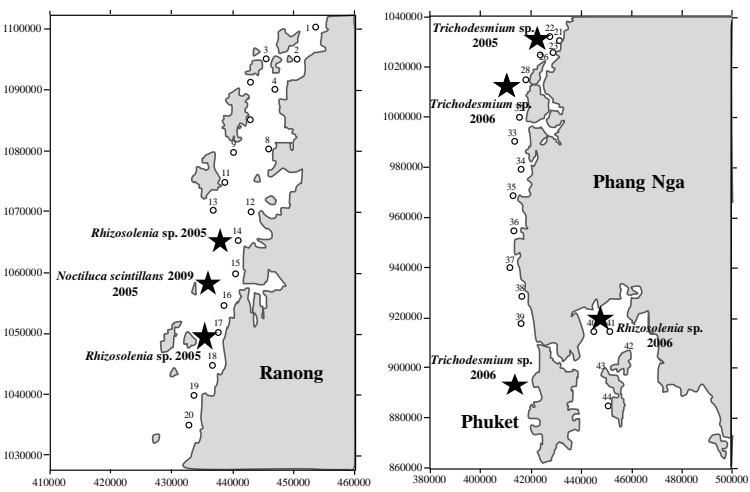

Fig. 5 Map of red tide incident locations in Ranong, Phang Nga, and Phuket provinces during field surveys from 2004-2009.

of Ranong River (station 1) and the eastern part of Ra island (station 24).

Chlorophyll a concentrations in Ranong ranged between 1.34 and $4.67 \mu \mathrm{g} / \mathrm{l}$ with a mean value of $2.37 \pm 0.75 \mu \mathrm{g} / \mathrm{l}$. The highest concentration of chlorophyll $a$ was found at the river mouth and in the adjacent area. In Phang Nga waters, chlorophyll $a$ concentrations ranged from $0.57-6.45 \mu \mathrm{g} / \mathrm{l}$ with a mean value of $2.0 \pm 1.6 \mu \mathrm{g} / \mathrm{l}$. Chlorophyll $a$ concentration at Khao Phing Kan (station 40), where the highest concentration of silicate-silicon and the lowest salinity were found, was $5.34 \mu \mathrm{g} / \mathrm{l}$.

Statistical analysis ( $t$-test, 0.99 confidence coefficient) showed that the seawater parameters in Ranong were significantly different from those in Phang Nga, except for water temperature, silicatesilicon, and chlorophyll $a$ concentrations.

\section{Red tide incidence}

The outbreaks of red tide were observed along the coastline areas during the field survey from 20052009 (Fig. 5). Rhizosolenia spp. red tides were found between stations 13 and 14, as well as between stations 17 and 18 during a 2005 survey. Furthermore, Trichodesmium erythraeum red tides were found at Ra island (nearby station 24) and western coast of Phuket island during a survey in 2006. The widespread occurrence of red tide caused by Noctiluca scintillans was also observed in the eastern part of Khang Khao island during the October 2009 survey.

\section{Coral bleaching}

Five months after the tsunami, the corals, especially Acropora spp., showed slight signs of recovery, but the corals here faced serious coral bleaching
Table 3 Length (in $\mathrm{cm}$ ) of primary branch of Acropora spp. around the study areas after 2004 tsunami.

\begin{tabular}{lccccc}
\hline \multirow{2}{*}{ Location } & \multicolumn{2}{c}{ May 2005 } & & \multicolumn{2}{c}{ February 2007 } \\
\cline { 2 - 3 } \cline { 5 - 6 } & Length & Average & & Length & Average \\
\hline Torinla island & $2.0-4.1$ & $3.0 \pm 1.2$ & & $13.0-15.5$ & $14.5 \pm 1.3$ \\
Tao Bay & $1.9-4.5$ & $2.9 \pm 0.9$ & & - & - \\
Phak Kat Bay & $3.7-4.1$ & $3.9 \pm 0.3$ & & $7.0-25.0$ & $14.2 \pm 5.8$ \\
Chong Khat & $3.6-8.8$ & $5.2 \pm 2.2$ & & $7.0-18.0$ & $14.2 \pm 4.6$ \\
Khang Khao & $1.2-7.6$ & $3.9 \pm 2.7$ & & - & - \\
Lan island & 3.8 & $3.8 \pm 0.0$ & & - & - \\
\hline
\end{tabular}

again (Fig. 6). The coral bleaching levels (survey in May 2005) could be categorized into four groups, namely, severe bleaching (bleaching of more than $80 \%$ ), moderate bleaching (bleaching of 50-79\%), slight bleaching (bleaching of 20-49\%), and minimal bleaching (bleaching less than 20\%). Fig. 7 shows the percentage of coral bleaching at $15 \mathrm{sam}$ pling sites around Phayam island. Both corals in the northern and southern parts of Phayam island were severely bleached whereas corals in the eastern part of this island were moderately bleached. The coral bleaching level at Khang Khao island ranged between slight to moderate bleaching (Fig. 7). Corals in all sampling sites in the eastern part of this island were slightly bleached. In addition, slightly bleached corals in this area were found during the survey in October 2009 (Fig. 6h).

Coral bleaching at Kam Yai, Kam Nui, and Lan islands ranged widely from minimal to severe bleaching (Fig. 8). The coral bleaching around Khaiyai island ranged from slight to severe bleaching. Fig. 9 shows the percentage of coral bleaching at 36 sampling stations around South-Surin and Torinla islands. Coral bleaching in these two islands ranged from slight to severe. At Torinla island, severe bleaching was observed where water depth was over $20 \mathrm{~m}$.

\section{Coral growth}

The growth of Acropora spp. (A. cytherea, A. formosa, A. tenuis, A. vaughani) in Surin Marine National Park, measured in May 2005, showed that corals at Torinla island could grow between 2.0 and $4.1 \mathrm{~cm}$ in 5 months, while the mean value was about $3.0 \pm 1.2 \mathrm{~cm}$ (Table 3). Around Tao bay and Phak Kat bay, corals could grow between 1.9 and 4.5 and 3.7-4.1 cm, with mean growth of $2.9 \pm 0.9 \mathrm{~cm}$ and $3.9 \pm 0.3 \mathrm{~cm}$, respectively. At Chong Khat bay, the most severely damaged by the tsunami, corals could grow between 3.6 and $8.8 \mathrm{~cm}$ with a mean 

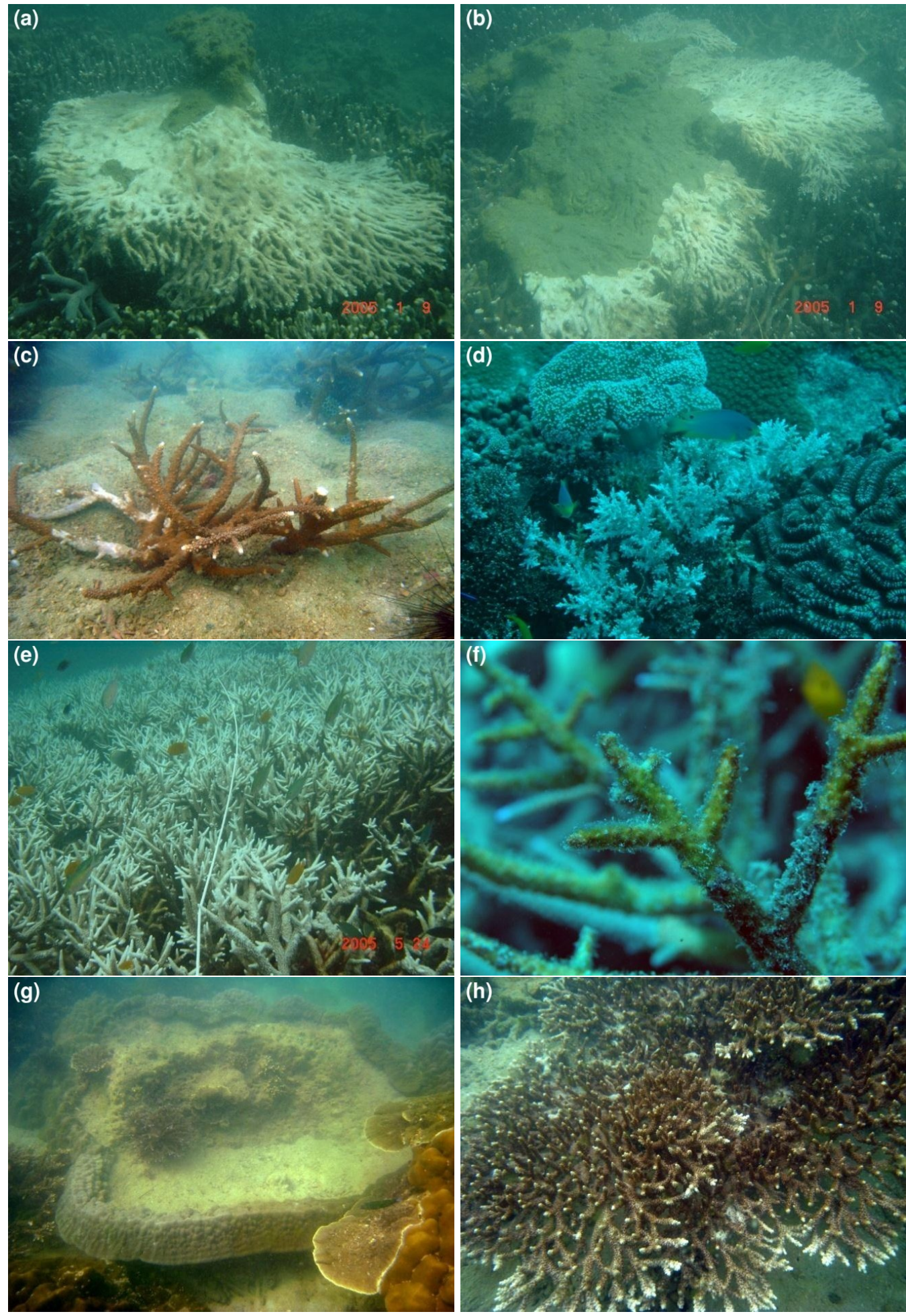

Fig. 6 (a, b, c) Morphology of Acropora spp. after attack by tsunami for 5 months; (d, e) coral bleaching occurring in both massive and branching corals in May 2005; (f) dead corals covered with macro algae and settled particulates in February 2007; (g) coral morphology at Khang Khao island in October 2009; (h) coral bleaching at Khang Khao island in October 2009. 


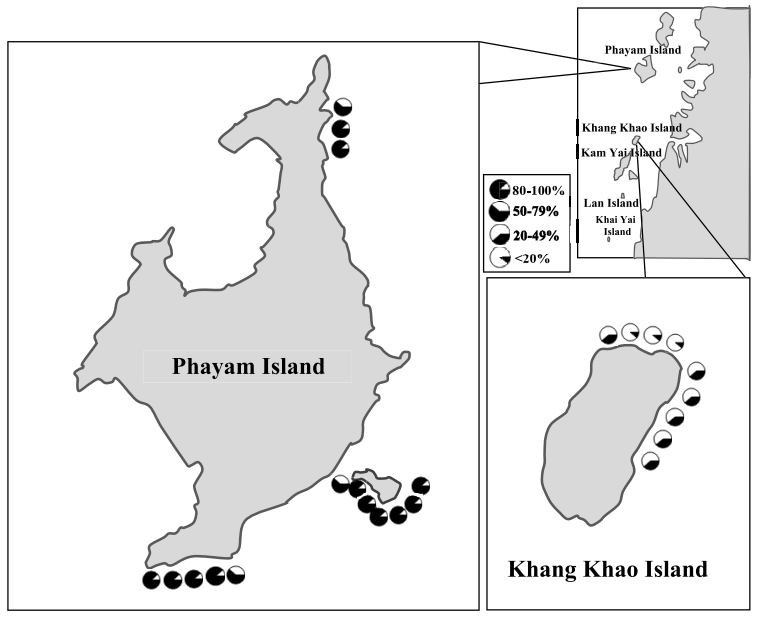

Fig. 7 Percentage of coral bleaching around Phayam and Khang Khao islands, Ranong, Thailand.

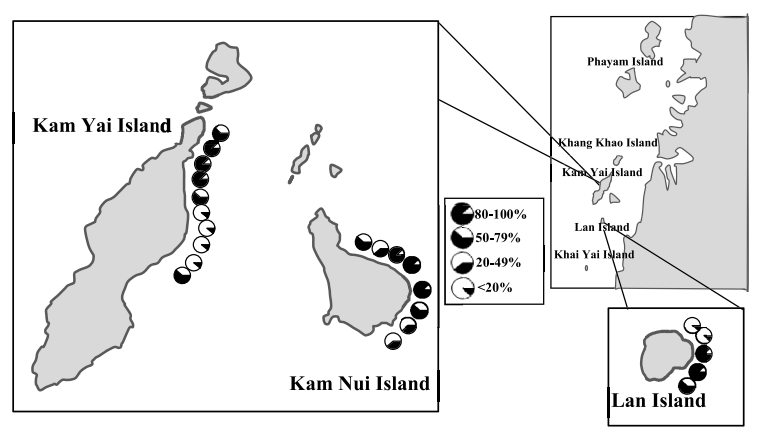

Fig. 8 Percentage of coral bleaching around Kam Yai, Kam Nui and Lan islands, Ranong, Thailand.

value of $5.2 \pm 2.2 \mathrm{~cm}$. Statistical tests (ANOVA, 0.95 confidence coefficient) carried out 5 months after the tsunami indicated that the coral growth rate at Chong Khat bay was significantly different from those at Tao bay and Phak Kat bay, while no significant difference was found between Tao bay and Phak Kat bay. In near shore areas such as Khang Khao and Lan islands, the growth of coral (determined in May 2005) were at a mean value of $3.9 \pm 2.7 \mathrm{~cm}$ and $3.8 \pm 0.0 \mathrm{~cm}$, respectively.

Three years after the 2004 tsunami, the corals in Surin Marine National Park was able to grow rapidly, while corals in near shore areas were found in a poor condition covered with macroalgae and settled particulates (Fig. 6f). The estimated growth of corals at Phak Kat bay in February 2007 indicated that corals (primary branch) could grow at the mean length of $14.2 \pm 5.8 \mathrm{~cm}$ while the mean length of whole areas of Surin Marine National Park was estimated to be

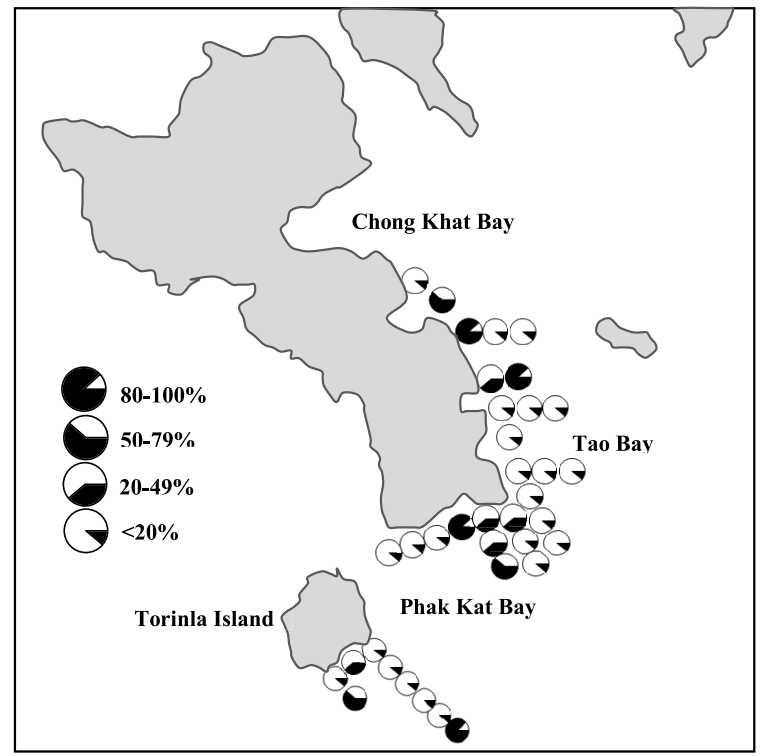

Fig. 9 Percentage of coral bleaching around Surin Marine National Park.

$13.4 \pm 5.2 \mathrm{~cm}$. Corals in near shore areas, such as Lan island, were almost dead and have been covered with macroalgae and settled particulates for three years after the tsunami. However, the corals around Khang Khao island (near shore area) showed slight signs of recovery in October 2009 (Fig. 6g).

\section{DISCUSSION}

\section{Seawater characteristics}

Elevation of sea temperature has long been suggested as an important factor inducing coral bleaching ${ }^{10,13}$. The results from current study on seawater characteristic demonstrated that the surface water temperature of the Andaman sea was higher than those of the water temperature in the past. Brown ${ }^{10}$ revealed the seasonal variation of water temperature of the Andaman sea during 19461996. They also proposed a relationship between seawater temperature and coral bleaching around the coast of Phuket, Thailand, and concluded that the critical seawater temperature for coral bleaching was $30.11^{\circ} \mathrm{C}$. According to this study, the average seawater temperature at Ranong and Phang Nga, areas close to Phuket, was estimated to be $30.56 \pm 0.37^{\circ} \mathrm{C}$ greater than the critical seawater temperature reported by Brown ${ }^{10}$. Recently, the frequency and distribution of coral bleaching in the Andaman coastline of Thailand has increased, especially during April and May. This could be one of the important reasons for the gradual decline of 
corals and reef areas over the years.

Corals can tolerate a wide range of salinities, i.e., between 15 and $50 \mathrm{psu}^{25}$. Our results indicate that the salinity of Andaman sea is still in the optimal range for coral growth, although freshwater runoff is gradually increasing due to the destruction of mangrove and inland forests along the Andaman coastline. The mangrove area in Ranong and Phang Nga Provinces was estimated to be from $21800-36700 \mathrm{ha}^{26}$. Thereafter, it has decreased to 19237 ha in 1998, then it increased to 25092 ha in 2004 due to the reforestation programme of the Royal Forestry Department. However, the natural inland forest was still reduced and substituted with monoculture of rubber trees. Silicate-silicon concentration in some study areas was quite high (over $25 \mu \mathrm{M}$ ). High concentrations of silicate-silicon can potentially stimulate the growth of benthic diatoms, which covers the coral and bottom sediments. Concentrations of ammoniumnitrogen $\left(\mathrm{NH}_{4}^{+}-\mathrm{N}\right)$ and orthophosphate-phosphorus $\left(\mathrm{PO}_{4}^{3-}-\mathrm{P}\right)$ in Ranong and Phang Nga waters were slightly low compared to the values in the Gulf of Thailand. Concentrations of $\mathrm{PO}_{4}^{3-}-\mathrm{P}$ in Ranong was markedly high $(0.34-0.77 \mu \mathrm{M})$ compared to the value obtained from the same area in $1992^{24}$. The results from Limpsaichol ${ }^{27}$ indicated that the average concentration of $\mathrm{PO}_{4}^{3-}-\mathrm{P}$ in Ranong area ranged from 0.13-0.24 $\mu \mathrm{M}$ during December 1990 to December 1992. Pollution Control Department reported that average concentrations of $\mathrm{PO}_{4}^{3-}-\mathrm{P}$ throughout the year in the southern part of Ranong (stations 19 and 20) were 0.03 and $0.07 \mu \mathrm{M}$ in 1997 and 2002, respectively. Our results confirmed that the nutrient concentration in the Andaman sea has soared. Although incidences of red tide are rare in the Andaman sea, outbreaks of Rhizosolenia spp. were found along the Andaman coastline during a survey in 2005, as well as T. erythraeum in the Phang Nga area during a survey in 2006. In addition, an occurrence of $N$. scintillans red tide covered the eastern part of Khang Khao island in 2009. Recent blooms of macroalgae such as Cladophora and Enteromorpha have been observed at Patong beach, Phuket island, during January and February 2005 and 2006, respectively. Tsunami run-up is also an issue regarding the nutrient enrichment of the Andaman sea. Thus after the tsunami in 2004, the frequency of the outbreak of red tide and macroalgal bloom seem to be increasing in the Andaman coastline.

The Andaman sea of Thailand has been well known for its clean and clear water. Nowadays, the
Andaman sea, especially in areas near the shore, is quite turbid and abundant in nutrients. Chlorophyll a concentration in the water column represents the turbidity and nutrient concentration in seawater. Limpsaichol ${ }^{27}$ reported that the average chlorophyll a content of seawater in the Ranong area was $0.47 \mu \mathrm{g} / \mathrm{l}$. However, our result suggested that the average chlorophyll $a$ content of seawater in Ranong increased to $2.37 \pm 0.75 \mu \mathrm{g} / \mathrm{l}$. Moreover, the chlorophyll $a$ content at Khao Phing Kan (station 40), a well-known tourist area, was higher than $5.0 \mu \mathrm{g} / 1$. These results show that water quality around this area has deteriorated. The increase in nutrient concentration in the Andaman sea is caused by both human activities and natural disasters. Social community expansion and an increase in the number of tourists are the main causes of nutrient enrichment in the Andaman sea. Although nutrient concentration and some seawater characteristics in Ranong and Phang Nga waters have significant differences, they had similar chlorophyll $a$ concentrations. This phenomenon suggests that the nutrient concentration of both study areas is enough and/or in excess, to support phytoplankton growth.

\section{Coral bleaching}

Coral bleaching in the Andaman sea has been reported by several authors over the last two decades $^{11,21,22}$. In the past coral bleaching mostly affected branching corals, but in this study bleaching was found to have affected both branching and massive corals. Although coral bleaching is associated with a variety of physiological stresses, the most important cause is elevated water temperature. Phongsuwan ${ }^{11}$ noted that about $80 \%$ of Acropora spp. in Surin islands died after bleaching in May 1995 when seawater temperature was $0.7^{\circ} \mathrm{C}$ higher than the critical temperature suggested by Brown ${ }^{10}$. In this study, some areas had seawater temperatures which were more than $1.4^{\circ} \mathrm{C}$ higher than the critical temperature, resulting in the bleaching of more than $80 \%$ of both branching and massive corals in near shore and offshore areas.

Serious coral bleaching also occurred in the eastern part of the Gulf of Thailand in 1995 resulting in the mortality of more than $70 \%$ of branching corals around shallow water areas. In the Andaman sea, coral bleaching phenomenon was an annual event even before the 2004 tsunami, although some corals were able to recover. However, the coral bleaching phenomenon in 2005 was different from former incidences, with mass coral mortality occur- 
ring along the Andaman coastline. Interestingly, after the 2004 tsunami, the coral reefs in deep areas (ca $25 \mathrm{~m}$ depth such as in Surin Marine National Park) could grow and recover very fast although they also faced serious bleaching. The coral reefs in the shallower waters along the Andaman coastal zones however was unable to recover within three years after serious bleaching. This situation could be due to light limitation from high turbidity in shallower zones, resulting in limited growth of symbiotic dinoflagellate in the coral. Recently, the high density of phytoplankton in the shallower waters along the Andaman coastal zones usually covered the reef areas leading to reduced light intensity. Moreover, red tide outbreaks have also occurred more frequently around the study site. As a consequence, the growth of symbiotic dinoflagellate in coral polyps was restricted.

\section{Growth of corals}

Since the corals along the Andaman coastline had been damaged over a vast area, a great number of samples were collected from each area. Although many Acropora species included in the samples might have caused variability in the growth between species, exactly settlement time, and those of individual branches due to their alignment or shading effects of one branch upon another, the data collected could demonstrate the sign of recovery and degeneration of coral reefs in the study areas. The growth of Acropora spp. around Surin Marine National Park, determined in May 2005, demonstrated that during the early period (5 months after tsunami) the growth rate of corals at Chong Khat bay $(1.0 \mathrm{~cm} /$ month $)$ was significantly different from the other study sites. There was no significant difference in growth rate of corals in Torinla island, Tao bay, and Phak Kat bay. Mean growth rate at all three sampling sites was estimated to be $0.6 \mathrm{~cm} /$ month. At Chong Khat bay, the most severely damaged area by the tsunami, corals were able to grow faster than at any other study site during the 5 months after tsunami. In the case of near shore areas, the growth of corals at both Khang Khao and Lan islands, determined in May 2005, had mean values of $0.8 \mathrm{~cm} / \mathrm{month}$. For long term monitoring, the growth of corals estimated around Surin Marine National Park in February 2007 showed that they had no significant differences in growth rates between sampling sites.

The mean length of the primary branch of corals at Phak Kat bay was estimated to be $3.9 \pm 0.3 \mathrm{~cm} 5$ months after the tsunami (about
$0.8 \mathrm{~cm} /$ month), and the mean length was estimated to be $14.2 \pm 5.8 \mathrm{~cm}$ three years after the tsunami (about $0.4 \mathrm{~cm} / \mathrm{month}$ ). Results indicate that corals around Surin Marine National Park were able to grow at a faster rate during the dry season (November-April) than during the wet season. Charuchinda and Hylleberg ${ }^{28}$ also reported that the growth rate of Acropora formosa in Phuket during the north-East monsoon (November-April) was about twice faster $(0.31 \pm 0.08 \mathrm{~mm} /$ day or about $0.9 \mathrm{~cm} / \mathrm{month})$ than during the South-West monsoon (April-October). This phenomenon is also similar to the growth of A. pulchra in the Philippines, reported by Yap and Gomez ${ }^{29}$, who suggested that the growth rate of $A$. pulchra was faster during the cool season (November-January) and was affected by the North-East Monsoon. They estimated the average growth rate of $A$. pulchra to be $15.3 \mathrm{~cm} /$ year. Previous studies reported a higher growth rate compared to the results of this study. This might be due to their short monitoring period or omitting some warm months ${ }^{30-32}$. Strömgren ${ }^{33}$ compared the growth rate of $A$. pulchra around Phuket Province, Thailand, as well as in the Philippines. He suggested that the growth rate of A. pulchra in the Philippines was markedly higher than that in Phuket due to higher water temperatures and stronger solar radiation.

\section{Conclusions}

After the occurrence of the tsunami in 2004, the concentration of nutrients (silicate-silicon, ammoniumnitrogen and orthophosphate-phosphorus) in the study areas increased due to tsunami run-up. Thereafter, chlorophyll $a$ in the water column gradually increased due to rapid growth of phytoplankton (red tide outbreak a few months after the tsunami), and severe coral bleaching also occurred due to the increase in seawater temperatures to levels higher than the critical temperature. These conditions resulted in a mass mortality of corals in shallow waters. Three years after the 2004 tsunami, the coral reefs in deep water areas could grow and recover rapidly although they faced serious bleaching. Whereas, coral reefs in the shallower waters were in a poor condition after serious bleaching in May 2005. Mass mortality of corals in shallow waters was enhanced by high seawater temperature and high turbidity due to phytoplankton blooms. Turbidity is thus considered to be the most important factor leading to the degradation of corals in near shore shallow areas. Our results indicated that the future of corals in the Andaman sea, especially in shallow 
coastal zones, is threatened. Although it is difficult to reduce seawater temperature levels caused by global warming in this region, it is possible to reduce phytoplankton density and other suspended particles in water column by decreasing nutrient loading and sediment runoff caused by domestic waste sediment and/or local deforestation. The coral population could vanish in the near future if stakeholders do not take action to tackle these problems.

Acknowledgements: We gratefully acknowledge Assoc. Prof. Jirarpast Adjimangkunl for her helpful comments. We especially thank Chakrit Ruangsorn, Chira Auopimma, Pharuhas Channuan, Pattrawut Thaipichitburapa and all members of Kasetsart University's Marine Environment Laboratory (Department of Marine Sciences) and Aquatic Sediment and Environmental Research Laboratory (Department of Fishery Biology) for their help and cooperation in both field surveys and laboratory analyses. A part of this study was funded by the Centre of Advanced Studies in Tropical Natural Resources, KU Institute for Advanced Studies, Kasetsart University and National Research Council of Thailand.

\section{REFERENCES}

1. Stein S, Okal EA (2005) Speed and size of the Sumatra earthquake. Nature 434, 581-2.

2. Jeyabaskaran R, Rao DV (2007) Impact of the December 24, 2004 Tsunami on coral reefs of Andaman and Nicobar Islands, India. Reef Encount 34, 25-30.

3. Gleason MG (1993) Effects of disturbance on coral communities: bleaching in Moorea, French Polynesia. Coral Reefs 12, 193-201.

4. Hoegh-Guldberg O, Salvat B (1995) Periodic massbleaching and elevated sea temperatures-bleaching of outer reef slope communities in Moorea, French Polynesia. Mar Ecol Progr 121, 181-90.

5. Ambarsari I, Brown BE, Barlow RG, Britton G, Cummings D (1997) Fluctuations in algal chlorophyll and carotenoid pigments during solar bleaching in the coral Goniastrea aspera at Phuket, Thailand. Mar Ecol Progr 159, 303-7.

6. McClanahan TR (2000) Bleaching damage and recovery potential of Maldivian coral reefs. Mar Pollut Bull 40, 587-97.

7. Mumby PJ, Chisholm JRM, Edwards AJ, Andrefouet S, Juabert J (2001) Cloudy weather may have save Society Islands reef corals during the 1998 ENSO event. Mar Ecol Progr 222, 209-16.

8. Sheppard CRC (2003) Predicted recurrences of mass coral mortality in the Indian Ocean. Nature 425, 294-7.

9. Wooldridge S, Done T (2004) Learning to predict large-scale coral bleaching from past events: A
Bayesian approach using remotely sensed data, insitu data, and environmental proxies. Coral Reefs 23, 96-108.

10. Brown BE, Dunne RP, Chansang H (1996) Coral bleaching relative to elevated seawater temperature in the Andaman Sea (Indian Ocean) over the last 50 years. Coral Reefs 15, 151-2.

11. Phongsuwan N (1998) Extensive coral mortality as a result of bleaching in the Andaman Sea in 1995. Coral Reefs 17, 70.

12. Dunne RP, Brown BE (2001) The influence of solar radiation on bleaching of shallow water reef corals in the Andaman Sea, 1993-1998. Coral Reefs 20, 201-10.

13. Glynn PW, D'Croz L (1990) Experimental evidence for high temperature stress as the cause of El Ninocoincident coral mortality. Coral Reefs 8, 181-91.

14. Lesser MP, Stochaj WR, Tapley DW, Shick JM (1990) Bleaching in coral reef anthozoans: effects of irradiance, ultraviolet radiation, and temperature on the activities of protective enzymes against active oxygen. Coral Reefs 8, 225-32.

15. Allison WR (1995) Changes in the Maldivian reef system. Coast Manag Trop Asia 4, 6-8.

16. Hoegh-Guldberg O (1999) Climate change: coral bleaching and the future of the world's coral reefs. Mar Freshwat Res 50, 839-66.

17. McWilliams JP, Côté IM, Gill JA, Sutherland WJ, Watkinson AR (2005) Accelerating impacts of temperature-induced coral bleaching in the Caribbean. Ecology 86, 2055-60.

18. Baker AC, Glynn PW, Riegl B (2008) Climate change and coral reef bleaching: An ecological assessment of long-term impacts, recovery trends and future outlook. Estuar Coast Shelf Sci 80, 435-71.

19. Fitt WK, Brown BE, Warner ME, Dunne RP (2001) Coral bleaching: interpretation of thermal tolerance limits and thermal thresholds in tropical corals. Coral Reefs 20, 51-65.

20. Tamelander J (2008) South Asia-Summary. In: Obura DO, Tamelander J, Linden O (eds) Coastal Oceans Research and Development in the Indian Ocean Status Report 2008, Part 1: Regional Summaries, pp 11-20.

21. Khokiattiwong S, Yu W (2012) Note on the occurrence of high sea surface temperatures in the Andaman Sea, in 2010. Phuket Mar Biol Cent Res Bull 71, 1-9.

22. Phongsuwan N, Yamarunpattana C, Paokanta S, Areechon P (2008) Status of coral reefs in the Surin and Similan Archipelagos, Thailand. In: Obura DO, Tamelander J, Linden O (eds) Coastal Oceans Research and Development in the Indian Ocean Status Report 2008, Part 2: Coral Reef Status Reports, pp 3-9.

23. Parsons TR, Maita Y, Lalli CM (1984) A Manual of Chemical and Biological Methods of Seawater Analysis, 
Pergamon Press, New York.

24. Veron J (2000) Coral of the World: vol. 1-3, Australian Institute of Marine Science and CRR Old Pty Ltd, Australia.

25. Coles SL (2003) Coral species diversity and environmental factors in the Arabian Gulf and the Gulf of Oman: A comparison to the Indo-Pacific region. Atoll Res Bull 507, 1-19.

26. Supapipat S (1988) Mangrove: Good policy but poor enforcement. Agro Ind Mag 36, 27-35, [in Thai].

27. Limpsaichol P, Khokiattiwong S, Bussarawit N (1992) Water Conditions and Nutrient Content at the Artificial Reef Sites in Ranong Province, Thailand. Scientific report, Phuket Marine Biological Centre, Phuket, Thailand. pp 11-5.

28. Charuchinda M, Hylleberg J (1984) Skeletal extension of Acropora formosa at a fringing reef in the Andaman Sea. Coral Reefs 3, 215-9.

29. Yap HT, Gomez ED (1984) Growth of Acropora pulchra II Responses of natural and transplanted colonies to temperature and day length. Mar Biol 81, 209-15.

30. Mayor AG (1924) Growth-Rate of Samoan Corals, Carnegie Institute of Washington Publication, pp 51-72.

31. Tamura T, Hada Y (1932) Growth Rate of Reef Building Corals Inhabiting in the South Sea Island. Scientific report, Tohoku Univ, pp 433-55.

32. Yap HT, Gomez ED (1982) Growth of Acropora pulchra (Brook) in Bolinao, Pangasinan, Philippines. In: Gomez ED, et al (eds) Proceedings of the 4th International Coral Reef Symposium, vol. 2, Manila, Philippines, pp 207-13.

33. Strömgren T (1987) The effect of light on the growth rate of intertidal Acropora pulchra (Brook) from Phuket, Thailand, lat. $8^{\circ}$ N. Coral Reefs 6, 43-7. 